Features of fiscal stimulation of sustainable development of regions...

\title{
FEATURES OF FISCAL STIMULATION \\ OF SUSTAINABLE DEVELOPMENT OF REGIONS IN MODERN CONDITIONS
}

\section{Polishchuk Vadym ${ }^{1}$}

DOI: http://dx.doi.org/10.30525/978-9934-571-28-2_22

Abstract. The purpose of the article is to study the conceptual foundations of sustainable development at the present stage, to determine the theoretical aspects of the fiscal space of the state, to analyze fiscal innovations regarding financial sustainability of sustainable development.

Methodology. The methodological basis of the research is the fundamental provisions of the theory of regional development, as well as the theory of motivation A. Maslow, K. Alderfer, V. Vroom, S. Adams, D. McGregor and K. Hallat et al. In general, the content and procedural theories are investigated. We have investigated that procedural theories are most suitable for motivating the development of regional socio-ecological and economic (CEE) systems, and they answer the question: "How should sustainable development of the region be stimulated?". In the process of research, we used the following methods: logical analysis - to generalize the theoretical foundations of stimulating the sustainable development of the region; graphic methods - to present the results of empirical studies in visual form (in particular, the schematic form); methods of analysis, synthesis and comparison - for the set and structure of indicators for analysis of the stimulation of sustainable development of the region.

Research results. We have added an understanding of the sustainable development of the regions. In particular, we understand this as a process of continuous transformation of the qualitative and quantitative characteristics of a regional (CEE) system aimed at achieving a dynamic balance between society, the economy and the environment, while respecting the principles of equilibrium. We have identified theoretical and methodological aspects of the fiscal space, in particular, we have defined the subjects of such financial relations in detail, we also define the content of fiscal policy and its types, tools and mechanism of fiscal policy as an indispensable component

\footnotetext{
${ }^{1}$ Candidate of Economic Sciences, Associate Professor, Lutsk National Technical University, Ukraine

(C) Polishchuk Vadym
} 
of financial incentives for sustainable development of regions. We have investigated that the modernized national fiscal system introduced such tax innovations as the development of the electronic document flow infrastructure as a set of processes for the creation, processing, transmission, receipt, storage, use of electronic documents used for checking integrity and remote auditing; introduction of electronic service and electronic verification; as well as creation of a taxpayer's electronic cabinet with the aim of improving the conditions of the payer in the electronic service.

Practical implications. We propose theoretical and methodological researches of fiscal stimulation of sustainable development of regional socio-ecological-economic systems and they have practical significance. In particular, they can serve as a modernization of fiscal architectures, the development of new legislation relating to modern tax administration, and the improvement of knowledge on sustainable development. We have studied the basic principles of sustainable development of the region: equality, balance, harmony, stability, competitiveness, security. We also identified the main strategic guidelines for the fiscal policy concept: improving the efficiency of using fiscal instruments through their orderly and systematic use and harmonizing the use of fiscal policy tools with the need to improve the well-being of citizens.

Value / originality. This research continues to develop the theory of stimulation of sustainable development of the region proposed by Gerasymchuk Z.V. and Polishchuk V.G. in 2010. Emphasis is put on fiscal stimulation, the search for new approaches to effective financial provision in terms of tax application in order to achieve the supported development of regional socio-ecological and economic systems in this study.

\section{Introduction}

Confirmation of the sustainable development of regional socio-ecological and economic systems becomes very relevant for Ukraine at the present stage of development. First of all, this is due to the difficult socio-economic and ecological condition of the regions, as well as the need to meet the priority needs of the regions. This can be achieved through the introduction of effective stimulus tools. We can attribute to them the effective tools of financial and economic direction - tax instruments. A large set of tax incentives and skillful implementation of tax policies have led to the rapid provision of sustainable development in foreign countries. An important role in this case 
is given to environmental taxes (eco-taxes). Unfortunately, all the benefits of environmental taxation are not fully used today in our country, which hinders the progress of Ukraine's regions towards sustainable development. Environmental taxation is an important tool for increasing the country's ecological safety, it is able to ensure the efficient use of natural resources, to finance environmental protection measures at the state and local levels, to stimulate economic interest of economic entities through tax incentives for investment in energy and resource saving technologies, etc. Such levers are, of course, used in the tax system of Ukraine, in particular, the Tax Code of Ukraine has introduced tax deductions, exemptions (exempted from: excise tax on sales of electric energy produced by coherent installations and using renewable sources, PIT funds provided by the international a financial institution for increasing energy efficiency, VAT when importing energy-saving equipment and materials into the customs territory of Ukraine, equipment used in renewable sources of energy, etc.) and others. [8]. We will try to find out the content of fiscal support during a stimulating impact on the regional systems of Ukraine in order to eliminate these inappropriateness.

\section{Conceptual bases of sustainable development of regions at the present stage}

In 1987, the International Commission on Environment and Development (ICED) in the report "Our Common Future", chaired by the former Prime Minister of Norway Brundland H.K. focused on the need for "sustainable development". They understood sustainable development as a development that would meet the needs of the present generation without compromising the ability of the future generation to meet their own needs. This wording concept is now widely used as a base in many countries. In addition, she argued that the main idea of human societies should be to revitalize the search for better life, well-being [2]. That is, it is quite understandable to us that without the stimulation of sustainable development, the welfare of the present, and especially of future generations, is impossible.

The term "sustainable development" was defined at the 1992 Rio Conference in the framework of the adoption of the "Agenda for the 21 st Century" as "development that meets the needs of the present, without endangering the ability of future generations to meet their own needs" [11]. All subsequent definitions of concepts assumed the very basis of this interpretation of sustainable development. Actually, the term "sustainable develop- 
ment" is quite controversial. This concept corresponds to constant / stable development, and even supported development. Quite interesting is the French version of this term $\mathrm{m}$ "developpment durable" - "durable / longterm development".

Sustainable development of the region in terms of Gerasymchuk Z.V. and Polishchuk V.G. can be understood as a process of constant conversion of qualitative and quantitative characteristics of the regional socio-ecological and economic (CEE) system aimed at achieving a dynamic balance between society, economy and the environment, while ensuring the welfare of present and future generations, while respecting the principles of equilibrium, balance, harmony, stability, competitiveness and security of the region [5].

The basic principles of the sustainable development of the region as a system to which stimulating tools are to be applied are as follows:

1. The principle of equilibrium of a regional socio-ecological-economic system involves the achievement of a state of dynamic equilibrium of a regional socio-ecological-economic system aimed at overcoming intra-system and external threats by activating internal potential opportunities.

The principle of equilibrium should be the key to the movement of the regional CEE system to sustainable development.

2. The principle of balancing economic, social and environmental subsystems within the framework of sustainable development of the region causes the consideration of the regional CEE system in the context of achieving the optimal balance of qualitative and quantitative characteristics of the regional socio-ecological and economic system.

3. The principle of harmony means the maintenance of harmony, or the interrelation between the social, economic and environmental spheres of the region. This is manifested in the fact that all the goals of regional development, which are to be achieved, the methods of their achievement are interconnected and aim at achieving the ultimate result of sustainable regional development. In the broad sense, harmony must exist between a person and his or her surrounding world.

The principle of harmony is especially important because a large number of researchers in the sustainable development of the region proceeded precisely from the harmonization of processes within the socio-ecological and economic system.

4. The principle of stability of all subsystems of sustainable development requires maintaining for the longest possible period the positive parameters 
of the development of the CEE system. Stability of regional development as an integral part of the country's economic stability consists of economic, political, social and other types of stability.

Stability of the social component of the CEE system implies stability of population dynamics, minimization of dependence on adverse environmental conditions, and ensuring social justice. The stability of the ecological subsystem of the CEE system involves a limitation as they are due to the need to protect the environment in order to preserve biodiversity and the quantity of flora and fauna. The stability of the economic subsystem of the socio-ecological and economic system implies economic development, which ensures the ability to meet future generations in natural resources, that is, the balance of satisfaction of energy flows and information between social and environmental subsystems.

5. The principle of competitiveness of subsystems of sustainable development envisages enhancement of the potential of the region to increase and effectively use competitive advantages in each subsystem of the region in order to ensure sustainable development of the region, as well as introduction of new achievements of scientific and technological progress in production, environment and social sphere of the region. It should be noted that the scientists understand the competitive ability of the region, its ability to provide competitive advantages in the productive use of resources and benefits to enhance human development, without violating the economic security of other regions and the country as a whole.

6. The principle of sustainable regional development security implies the use of the potential of the regional socio-ecological and economic system, its ability to self-redevelopment and the prevention of destabilizing factors.

The security of the region is also the strength of interconnections between the elements of the regional system, which promotes satisfaction of the interests of the population of the region in the key of national interests.

The complex of measures stimulating the character will contribute to the achievement of the state of equilibrium regional system and the emergence of the nonequilibrium state of the regional socio-ecological and economic system.

We understand that the sustainable development of regions is the object of stimulation. Sustainable development is not the current state of the regional system, or even the national one. Instead, the sustainable devel- 
opment of the region is a prospect, a priority, to which one must strive. It should be remembered that the stimulating tools influence the system's aspirations to achieve sustainable development of the region and to get out of the present state of the regional system. It is clear that any regional system seeks to prevent the state of imbalance. However, due to the actions of various factors (external and internal), the initiative to achieve sustainable development of the region may be stopped at the beginning.

Therefore, sustainable development needs to be stimulated:

1)for the achievement of the sustainable development as a strategic goal;

2) for the achievement of the dynamic equilibrium of the regional socio-ecological and economic system;

3) for the achievement of the optimal ratio of qualitative and quantitative characteristics of the regional CEE system, namely, achieving the balance of sustainable development of the region;

4)for the achievement of the relationship between the social, economic and environmental spheres of the region, that is, the achievement of harmony;

5) for the maintenance of the long-term positive parameters of the development of the regional CEE system, namely the achievement of the stability of sustainable development of the region;

6)for the intensive of the potential of the region to increase and effectively use competitive advantages in the social, economic and environmental spheres of the region, that is, to achieve the competitiveness of the region;

7) for the achievement of the ability of the regional CEE system to self-replicate and prevent the action of destabilizing factors, namely the achievement of the security of sustainable development in the region.

Research on the sustainable development of regional CEE systems and the activation of entities engaged in financial and economic activities in their territory was conducted on the basis of the theory of regional development, as well as such well-known theory of motivation as:

a) content (reflect the content of needs): the theory of needs by Tugan-Baranovsky M.; the needs hierarchy theory by Maslow A.; theory of existence, relations and growth by Alderfer K., the theory of " $\mathrm{X}$ " and " $\mathrm{Y}$ " by McGregor D.; the theory of counter needs by McClelland D.C., two-factor theory of motivation, by Hertzberg F.;

b) procedural (reflect the rewarding process): theory of expectations by Vroom B.; theory of justice (impartiality) y Adams S.; the theory of participative (common) management; the theory of productive valence by Atkin- 
son J.; the theory of material incentives for labor; theory of reinforcement by Skinner B.F.; the complex theory by Porter L. and Lawler E.

The content theories of motivation that reveal the content of the needs of the regional system, answer the question - "Why do we need to stimulate?" However, the most suitable for motivating the development of regional socio-ecological and economic systems are procedural theories, answering the question: "How do we it is necessary to stimulate the sustainable development of the region?".

The main features of the above theories and their interpretation in the context of stimulating the sustainable development of the region are given in Table 1.

Table 1

\section{Characteristics of some theories of motivation in the context} of the promotion of sustainable development in the region

\begin{tabular}{|c|c|c|c|}
\hline Access & $\begin{array}{l}\text { Theory of } \\
\text { motivation }\end{array}$ & $\begin{array}{c}\text { Content theories of } \\
\text { motivation }\end{array}$ & $\begin{array}{l}\text { Content theory of motivation (at } \\
\text { the regional level in the context } \\
\text { of the promotion of sustainable } \\
\text { development) }\end{array}$ \\
\hline 1 & 2 & 3 & 4 \\
\hline \multirow{3}{*}{ 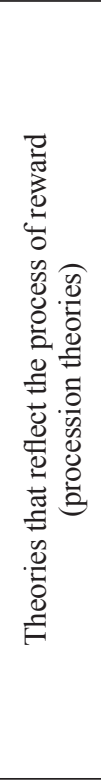 } & $\begin{array}{l}\text { Vroom's } \\
\text { Expectancy } \\
\text { Theory }\end{array}$ & $\begin{array}{c}\text { Man directs its efforts } \\
\text { on achieving any goal } \\
\text { in the extent to which } \\
\text { estimates the probability } \\
\text { of reward for it. }\end{array}$ & $\begin{array}{l}\text { Implementation of the scheme } \\
\text { "incentives-sustainable development" } \\
\text { x "sustainable development, obtain } \\
\text { benefits for the region" x "satisfying } \\
\text { benefits in regional CEE system" = } \\
\text { motivation (the desire for sustainable } \\
\text { development). }\end{array}$ \\
\hline & $\begin{array}{c}\text { Equity } \\
\text { theory on job } \\
\text { motivation }\end{array}$ & $\begin{array}{c}\text { Workers have compared } \\
\text { their rewards to the } \\
\text { effort and reward other } \\
\text { employees who perform } \\
\text { similar work. }\end{array}$ & $\begin{array}{l}\text { Terms of achieving sustainable } \\
\text { development for all regions } \\
\text { should be equal. However, to } \\
\text { achieve sustainable development } \\
\text { of the region need to use different } \\
\text { approaches, methods and tools, but } \\
\text { their use should be fair for everyone. }\end{array}$ \\
\hline & $\begin{array}{l}\text { The } \\
\text { theory of } \\
\text { participatory } \\
\text { management }\end{array}$ & $\begin{array}{l}\text { Active participation } \\
\text { of employees in the } \\
\text { organization's life, } \\
\text { communicating with } \\
\text { colleagues, enhances } \\
\text { job satisfaction, thus } \\
\text { increasing the quality of } \\
\text { their work. }\end{array}$ & $\begin{array}{l}\text { Involvement of regional management } \\
\text { and implementation of policies to } \\
\text { stimulate sustainable development } \\
\text { of the region business community, } \\
\text { financial institutions, public } \\
\text { asset territorial unions, research } \\
\text { institutions. }\end{array}$ \\
\hline
\end{tabular}




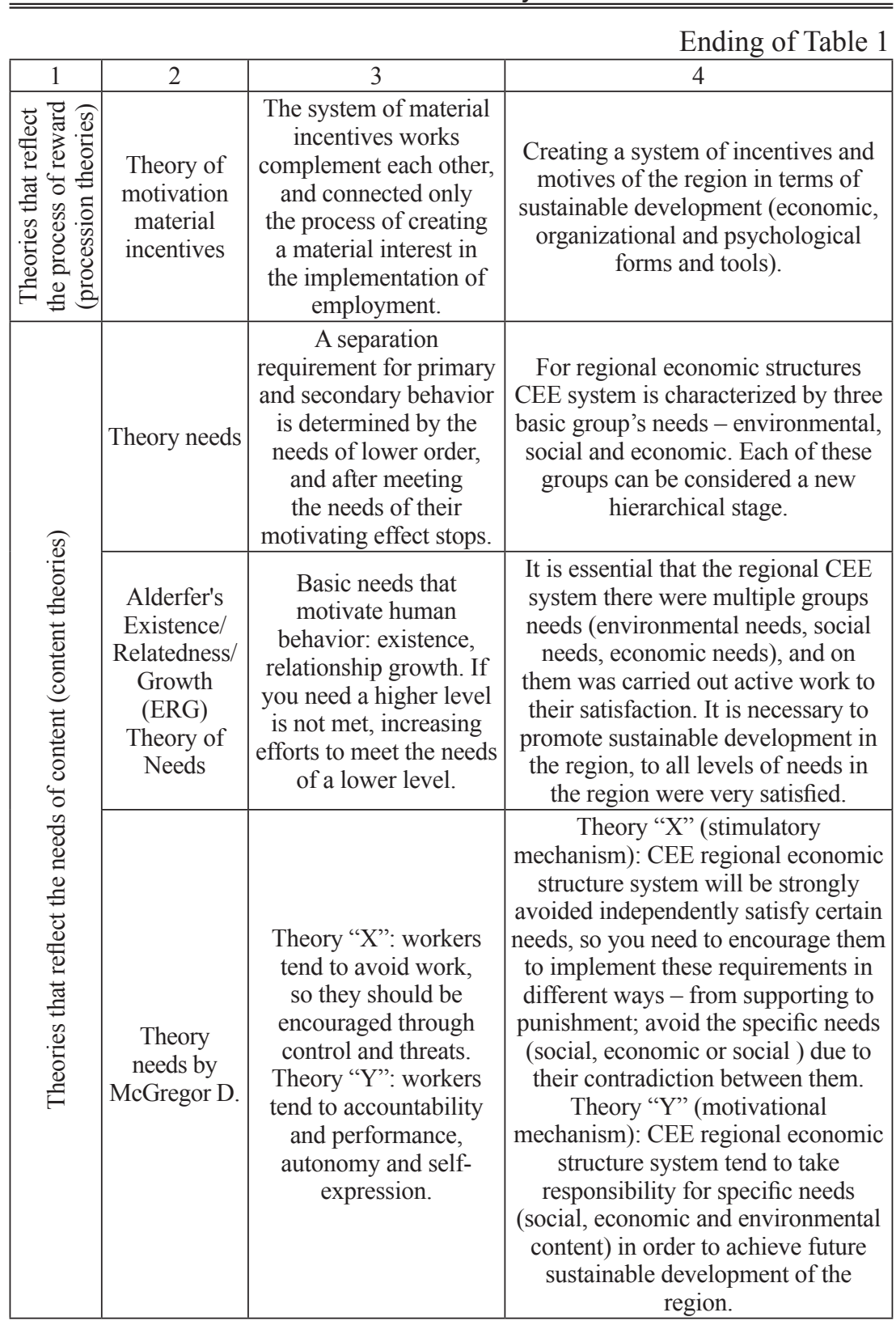


Features of fiscal stimulation of sustainable development of regions...

Result is the last link in the chain, but it is extremely difficult to achieve. An active entity (state and regional authorities) aims to fulfill its functions and duties related to providing social, economic and environmental development at present and in the future - sustainable development. It is safe to say that the activities of the subjects are behavioral in nature. The activity of all subjects to stimulate the region provides a synergistic effect, since all efforts to improve the situation in the region, according to the theory of participatory management, provide even greater results.

However, this scheme is general, and reflects the basic positions of the theory. Consider it in more detail in terms of each element of sustainable regional development - economic, social and social (see Figure 1).

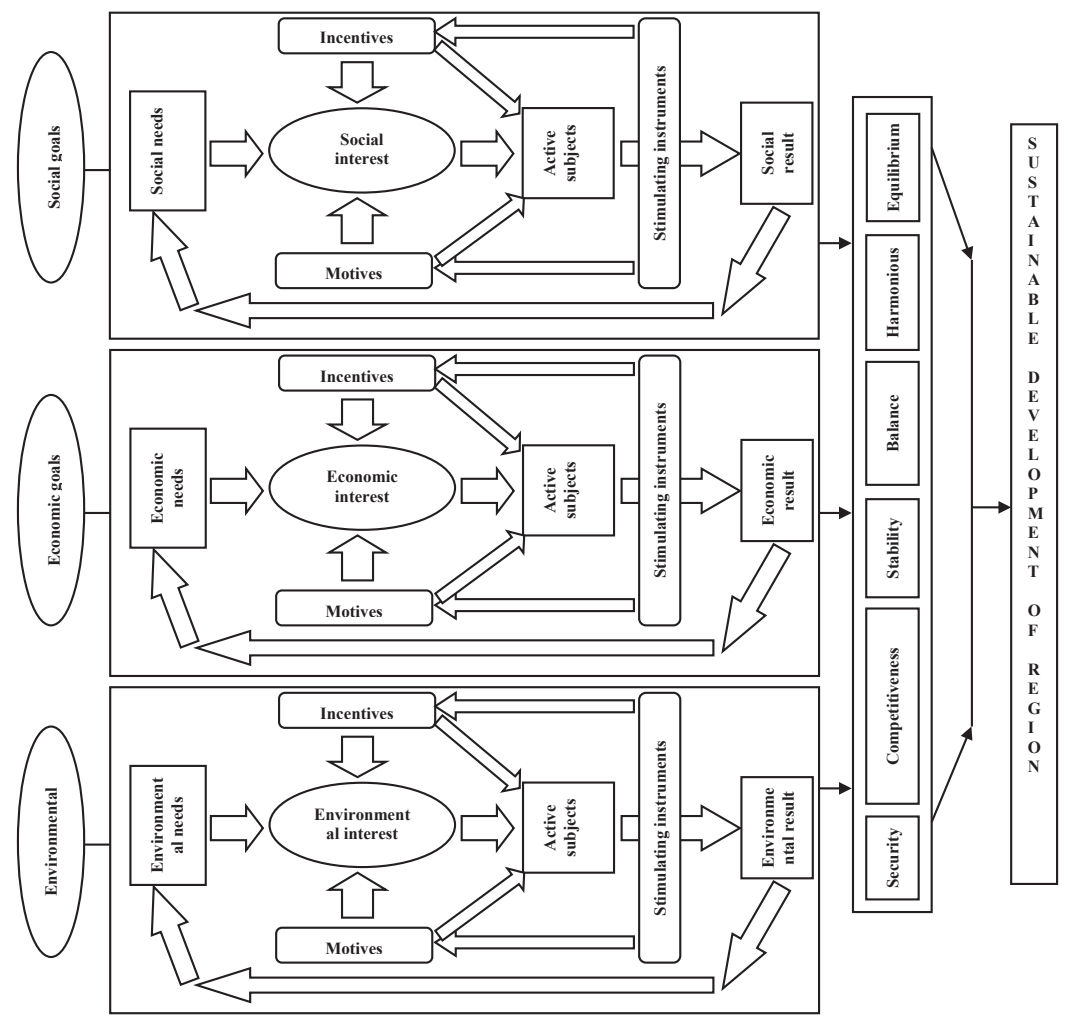

Figure 1. The theoretical approach to stimulation of sustainable development in the region 
Selection policy of stimulation of sustainable development of the region consists in taking into account the level of stimulation sustainable development in the region and the level of sustainable development in the region and allows to distinguish different types of policy of stimulating [12].

\section{Theoretical aspects of the fiscal space of the state}

According to Krisovaty A.I., Sidorovych O.Yu., complex processes and complementary interactions occurring at different levels of the fiscal space determine its essence through the prism of measurements of social being, with which it is in a constant dialectical relationship. The fiscal space as a derivative of the economic space in general is a form of realization of economic phenomena and processes that take place as a result of the existence of certain types of interactions carried out in accordance with established norms, "rules of the game", status roles and interests of the participants.

In this context, fiscal interactions are specific forms of interaction between individuals and their groups with the state or state institutions regarding the creation, distribution and redistribution of value added, which are implemented within tax institutions at a certain level of fiscal space in accordance with the multidimensionality of interaction models, their forms of implementation, status roles, positions and interests of the participants [15].

It is worth agreeing with the statements of the aforementioned scholars that fiscal space, depending on the spatial-temporal coordinates and the spectrum of propagation, can be global, interstate, state and local, each of which is characterized by tendencies of expansion and collapse. The collapse of the fiscal space of the state is conditioned by the dysfunction of the institutions, the termination of the fulfillment of their established and defined tasks. At the same time, the complete elimination of individual tax institutes is impossible, since it is conditioned by the stable, long-lasting nature of existence, the presence of a kind of "institutional memory", which directly depends on the peculiarities of the previous development. Even with the termination of an individual institution, its influence remains in the institutional space as an experience potentially existing in it.

The tax policy of any state should be determined not by the current needs of filling the revenue part of the budget, but, as Shnipko S. rightly observes, "to be based on long-term goals of stimulating the competitiveness of domestic producers, and hence of the national economy as a whole" [17]. 
The tax policy of the state should regulate the tax policy of regional systems, meet the needs of regions, promote the development of production and services in the region, and ensure social welfare. In addition, it must regulate the ecological processes in the region through economic mechanisms.

Therefore, the tax policy of the region involves choosing the composition and structure of taxes and fees, defining taxpayers, setting tax rates, benefits, etc. In the opinion of Gerasymchuk Z.V., the tax policy of the region is an integral part of fiscal policy, the content of which is to optimize the revenues and expenditures of budget funds for the purposes of sustainable development [4].

The state is the only entity that conducts fiscal policy in the person of individual authorities. This concept is considered in the world fiscal theory as a change in government expenditures and taxation [7]. Therefore, at first glance, the impression is that the main government body conducting fiscal policy is the government. However, legislative power is dominant in fiscal policy implementation. This is explained by the fact that important changes in the taxation process, which determine fiscal policy, are clearly realized through the adoption of certain normative legal acts by the legislature. The same applies to the policy of state expenditures, the strategic guidelines of which are laid down in the budget law for the relevant year.

The State Fiscal Service of Ukraine is the regulatory body in the field of taxation, the main task of which is the implementation of the state tax policy and policy in the field of state customs business, implementation within the limits of authority control over the receipt of taxes and duties, customs and other payments, etc.

Taxpayers as subjects of fiscal policy perform the function of calculation and payment of taxes, duties, and obligatory payments. According to the Tax Code of Ukraine, taxpayers are individuals (residents and non-residents of Ukraine), legal entities and their separate units that have, receive tax objects or carry out activities that are subject to taxation. Such individuals and legal entities must pay taxes and fees in a timely manner [9].

Financial relations reflect the interaction between the subjects of fiscal policy in the process of formation (the interaction of the state and economic entities and individuals - taxpayers and their carriers), distribution and use (interaction of state and citizens receiving public goods) of funds of funds. That is, the interests of the subjects of fiscal policy encourage them 


\section{Polishchuk Vadym}

to interact with each other in financial relations, resulting in one or another behavior.

The state applies appropriate tools for fiscal policy. Tax revenues and budget expenditures refer to such instruments, and more precisely tax regulation and regulation by means of expenditures, since the State Budget envisages both revenues and expenditures. Such a thesis is held by Banton V.D. and Konovalova I. [1; 6].

Transfer regulation and regulation of public debt also belong to the list of fiscal policy instruments. We agree with this thesis, because transfers are a redistributive mechanism for the formation of expenditures of individual budgets, on which the efficiency of financing public goods depends. Accordingly, the debt policy of the state is a means of generating budget revenues, which in modern socio-economic conditions is widely used by many states to finance the budget deficit.

The main tasks of the fiscal policy of the state are to change the real volume of national production and employment, control over inflation and accelerate economic growth.

Fiscal policy instruments can also be applied differently depending on the type of fiscal policy that is divided into discretionary and non-discretionary. Discretionary fiscal policies affect real output, employment and inflation through changes in tax revenues, budget expenditures and other instruments. Non-discretionary fiscal policy manifests themselves by the fact that tax revenues have the property to grow in proportion to GDP growth.

The conditions for the formation of financial relations as an element of the fiscal space system are determined by a number of factors. The most important conditions are the economic, social and environmental conditions of formation.

Fiscal space as a peculiar shell of the functioning of subjects of fiscal policy, defines the behavior of subjects. Each subject of fiscal policy decides how to act in certain situations and how to react to the behavior of other subjects under the influence of the described conditions for the formation of financial relations.

The state needs to take into account the mentality and cultural traditions of the nation when applying the tools of fiscal policy, to analyze the behavior of society in certain situations.

We need to clearly define not only tactical, but also, especially important, strategic goals for the formation of an effective fiscal policy. The 
fiscal policy concept must take into account the following strategic orientations:

- improving the efficiency of the use of fiscal instruments through their orderliness and system use;

- harmonization of the use of fiscal policy tools in order to improve the well-being of citizens;

- legal regulation of the mechanism and tools of fiscal policy, regardless of socioeconomic status and political factors of influence;

- scientific and economic justification of the relation between current expenditures and development expenditures.

\section{Fiscal innovation in financial support to sustainable development}

Financial innovations, as well as any other innovation, can also be divided into the following:

- crisis innovations, the main feature of which is the solution of the problem of the sale of goods (works, services) in connection with falling demand for it and reducing its sales, as well as a more complex problem the survival of the entity in the market in conditions of severe competition. Crisis innovation is aimed at eliminating the organizational, industrial, economic or financial crisis of the business entity;

- development innovations aimed at increasing the competitiveness of the product and the economic entity itself in the future. Such innovations are caused by promising forecasts of economic activity, such as forecasts of loss of competitiveness of goods, falling image of the business entity, possible bankruptcy;

- new financial transactions, which include forms of control and accounting of cash flows and securities (money changers), financial planning methods, methodology for drawing up financial plans of different types (balance of incomes and expenses, cash flow plan, budgeting, operational financial plans and etc.), methods of financial analysis, forms of organization of financial work of the business entity, interactive and other similar investment of capital and other actions related to an attempt to seize an economic entity, actions from catching up of new financial markets;

- new financial products, which are a form of materialization of such financial transactions that are intangible, therefore they can't be sold. They are embodied in the form of instructions, rules, guidelines, formulas, graphs, 
that is, some kind of document, which, in turn, is a financial product, and therefore, the object of sale [3].

The introduction of new effective tax instruments will have an impact on the promotion of innovative economic development. Innovations should become the basis for increasing the competitiveness of the national economy in general and all subjects of the regional socio-ecological-economic system in particular, which is impossible under the current tax system. However, there is no proper effect from the ongoing reforms in this area, since the taxes generally remained high and the tax base is too narrow. Therefore, opaque schemes, in particular regarding the reimbursement of value added tax on export operations, as well as tax legislation are generally too unstable, continue to apply. Therefore, the need to update the constructive and effective mechanisms of financial, in particular, tax, stimulation of innovation activity, is actualized.

In Ukraine, the government has long used such tax innovations as VAT bonds. They are government bonded bonds, as well as the special financial instruments that were created by the state to partially offset the violated rights of economic entities that are violated by the state itself. Such a violation consisted of the arbitrary use by the state of working capital of enterprises by holding a budget reimbursement of VAT [14].

The quality of taxpayer servicing by the bodies of the State Fiscal Service of Ukraine is constantly increasing due to the introduction of electronic document circulation and new reporting mechanisms by submitting tax reporting by electronic means. We also consider this a type of tax innovation.

The bodies of the State fiscal service of Ukraine are constantly introducing innovative transformations for continuous operational control of the formation of the revenue part of the State Budget. Thanks to such a transformation, the state body introduced a system of electronic administration of value added tax (SEA VAT).

From July 1, 2015, VAT payers should not only submit VAT reporting electronically, but also register the tax invoices electronically in the Unified Register of Tax Bills. SEA VAT is intended to destroy tax evasion schemes, in particular through the creation of offshore companies or the use of settlements through the conversion of commercial banks. Thus, the established SEA VAT is an effective step towards harmonization of the mechanism of VAT charging to a similar mechanism in the countries of the European 
Union when payment is made on the fact of consumption in a timely manner and in full [16].

Today, the modernized national fiscal system has introduced the following tax innovations:

- development of the electronic document flow infrastructure as a set of processes for the creation, processing, transmission, receipt, storage, use of electronic documents used for the verification of integrity and remote auditing;

- introduction of electronic service and electronic check-up;

- creation of a taxpayer's electronic cabinet in order to improve the conditions of the payer in the electronic service;

- providing tax consultations at the lowest level;

- formation of tax knowledge base;

- establishment of service centers for taxpayers;

- introduction of the system of electronic administration of VAT payers;

- creation of a mechanism for transparent electronic control of returning VAT payers;

- introduction of the possibility of receiving a taxpayer in electronic form a certificate of the absence of tax arrears;

- convergence of accounting and tax accounting when taxing corporate profits;

- reducing the number of tax audits of taxpayers by controlling bodies.

Today it is worth moving on to an effective innovation-investment model of the economy. For this purpose, the state should use a set of incentives, primarily of a fiscal nature. One of the most effective and most popular tools for support and tax incentives for innovation is tax breaks, including investment tax credit, research tax credit and investment tax rebate. At the same time, a tax credit is considered a sufficiently effective tax advantage - the amount at which taxes may be reduced, in connection with the implementation of innovation activities. The state, by providing tax privileges, works to increase the competitiveness of the country's economy and the rivers, which results in further chain effects on various components of socio-economic development, in particular the introduction of energy saving and innovative technologies, and modernization. In the long run, the state forms the potential for increasing the welfare of citizens.

The financial support of the policy of stimulating sustainable development in the region is a purposeful process that involves attracting, distributing and redistributing funds to finance incentive measures to achieve 
the social, economic and environmental goals of the region, with the main objective being the achievement of a sustainable development of the region with respect for all signs of constancy. The main subjects of the financial support of the policy of stimulating the sustainable development of the region are the subjects of the economy of the region, state and regional authorities and households. In accordance with this, the objects of financial support will be the finances of business entities in the region, public finances of the region and the finances of households in the region [13].

One of the types of financial support for a policy of stimulation of sustainable development of regional systems is tax stimulation of sustainable development of the region. The tax stimulation of sustainable development of the region have a significant impact: the finances of commercial enterprises of all forms of ownership operating in the region, the finances of the social institutions operating in the region, the finances of public institutions and charitable foundations operating in the region, as well as the finances of households in the region ( the funds of such business entities should be taxed in accordance with the current legislation of Ukraine in accordance with the established procedure); consolidated budget of the region and funds of state-owned trust funds operating in the region (redistribution of received taxes, fees and payments is made and directed to current and capital expenditures of the region).

Tax reform is a key task in solving job creation and environmental issues. It is especially important in the context of financial support for sustainable development of the region. Depending on the type and size, eco-taxes promise several benefits: introduce the principle of "paying the polluter" - internalize externalities associated with depletion and pollution, transforming them into internal production costs; provide incentives for more efficient use of energy and resources (reducing the flow of resources) and promoting technological innovation.

That is, environmental tax revenues should be reallocated through the budget (state or local budgets), contributing to the following objectives:

1) reduction of harmful emissions into the environment (air, water environment);

2) reduction of morbidity and increase of population productivity;

3 ) increase the revenue part of budgets of different levels.

The tax mechanism, which is an independent link of the economic mechanism and an important component of the financial mechanism, determines 
and legally establishes the forms of resource mobilization through taxes, fees and other tax payments.

On the one hand, taxes, providing revenue part of the state budget, determine the scale of social development, public financing of innovation projects, etc. On the other hand, the greater degree of toughness of the tax regime has a deterrent effect on the increase in output (and income), contributes to the growth of the shadow economy and thus, in the end, reduces the tax base.

One of the permanent and always topical issues in the aspect of tax incentives for sustainable development is the taxation of corporate profits. Taking into account the peculiarities of the Ukrainian economy, the stimulating mechanism of the corporate profit tax should be set up in such a way that it contributes to the development of production, the accumulation of capital and the return of the economy towards science and capital intensive industries, which in turn requires: the definition of the object of taxation; the establishment of tax rates; definition of a list of tax privileges and conditions for their provision of business entities.

The experience of developed countries (Denmark, Italy, Netherlands, Norway, Great Britain, Finland, Switzerland, Sweden, Belgium, Austria, United States, South Korea and Japan) shows that highly relevant today promoting sustainable development through tax instruments. Therefore, Ukraine should, taking into account the experience gained in these countries, take over and adapt it to our conditions.

A clear and balanced fiscal policy in this regard will allow in the shortest time to overcome the negative processes in the socio-economic and environmental sphere, and in the short term - to achieve sustainable development of regional socio-ecological and economic systems. The primary measures for this purpose are: the introduction of amendments to existing regulations (codes, laws, regulations), supplementation of the Tax Code of Ukraine (taking into account elements of tax incentives-through environmental taxes, environmental tax privileges), elaboration of the method of tax incentive measures within the tax politics [10].

\section{Findings}

Tax innovations will lead in the near future to improve the situation with the fiscal space of the state, and hence stable regional socio-ecological and economic. The development of partnerships between taxpayers 
and fiscal authorities will be one of the prerequisites for stabilizing the socio-economic development of the state as a whole, and the sustainable development of regional systems in particular. The current infrastructure of electronic document circulation as one of the indications of fiscal stimulus for sustainable development of the region will allow for the transition to a remote audit without additional costs for both the budget and taxpayers.

In view of the innovative development of the national tax system, some aspects of the transformation of the field of tax legal relations can be formulated: the gradual transition from the purely administrative-fiscal to the service model of relations between taxpayers and tax authorities; codification of tax knowledge with their respective internal distribution into special regimes; application of the relevant tax regimes by the state and their use by taxpayers to choose the best approach to fulfilling tax obligations.

\section{Conclusions}

In the process of theoretical and methodological research, we propose the main approaches to understanding the fiscal stimulation of sustainable development of regional socio-ecological and economic systems. We have identified a qualitatively new instrument of fiscal policy with the need to improve the well-being of citizens. We identified the main strategic guidelines for the fiscal policy concept, namely: improving the efficiency of using fiscal instruments through their orderliness and system use.

\section{References:}

1. Banton V. D. L., Tarangul V.I. (2010) Fiskalna polityka ta mekhanizm yii realizatsii [Fiscal policy and the mechanism of its realization]. Investments: practice and experience, no. 21, pp. 30-35. [in Ukrainian]

2. Bilorus O.G. (2005) Hlobalna perspektyva i stalyi rozvytok [Global Perspective and Sustainable Development]. K.: MAUP. [in Ukrainian]

3. Vakhnovskaya N.A., Ishchuk L.I., Polishchuk V.G. (2015) Suchasni podatkovi innovatsii yak priorytetna skladova finansovoho inzhynirynhu biznes-protsesiv v Ukraini [Modern tax innovations as a priority component of financial engineering of business processes in Ukraine]. Actual problems of the economy, no. 8, pp. 337-342. [in Ukrainian]

4. Gerasymchuk Z.V. (2008) Rehionalna polityka staloho rozvytku: teoriia, metodolohiia, praktyka: Monohrafiia [Regional Policy of Sustainable Development: Theory, Methodology, Practice: Monograph]. Luck: Nadstyr'ya. [in Ukrainian]

5. Gerasymchuk Z.V., Polishchuk V.G. (2011) Stymuliuvannia staloho rozvytku rehionu: teoriia, metodolohiia, praktyka: Monohrafiia [Stimulating the Sustainable Development of the Region: Theory, Methodology, Practice: Monograph]. Luck: RVV LNTU. [in Ukrainian] 


\section{Features of fiscal stimulation of sustainable development of regions...}

6. Konovalova I. (2014) Transformatsiia zmistu fiskalnoi polityky: tsili ta vzaiemozviazky [Transforming the content of fiscal policy: goals and interconnections]. Securities Market of Ukraine, no. 9-10, pp. 11-24. [in Ukrainian]

7. McConnell K.R., Brue S.L. (1992) Jekonomiks: principy, problemy i politika [Economics: principles, problems and politics]. M.: Respublika. [in Russian]

8. Nikitshin A. (2017) Podatkove rehuliuvannia yak instrument derzhavnoi ekolohichnoi polityky [Tax regulation as an instrument of state environmental policy]. Foreign Trade: Economics, Finance, Law, no. 2, pp. 128. [in Ukrainian]

9. Podatkovyi kodeks Ukrainy [Tax Code of Ukraine] Retrieved from: http://zakon2.rada.gov.ua/laws/show/2755-17/paran785\#n785 (accessed 08 March 2018)

10. Polishchuk V.G. (2010) Perspektyvy podatkovoho stymuliuvannia staloho rozvytku rehioniv Ukrainy [Prospects for tax incentives for the sustainable development of Ukrainian regions]. Economy and the State, no. 4, pp. 59-61. [in Ukrainian]

11. Intelsfera (2000) Prohrama dii "Poriadok dennyi na KhKhI stolittia": Ukhvalena konferentsiieiu OON z navkolyshnoho seredovyshcha i rozvytku $v$ Riode-Zhaneiro (Samit "Planeta Zemlia”, 1992 r.) [Agenda 21: Adopted by the UN Conference on Environment and Development in Rio de Janeiro (Summit "Earth", 1992)]. K.: Intelsfera [in Ukrainian]

12. Polishchuk V.G. (2017) Theoretical foundations of the concept of stimulating sustainable development of regions in the context of financial security. Economics and Society, no. 11, pp. 363-370.

13. Vakhovich I.M. (ed.) (2014) Finansove zabezpechennia staloho rozvytku rehioniv Ukrainy: mizhbiudzhetni vidnosyny ta innovatsiini instrumenty stymuliuvannia: Monohrafiia [Financial Support to the Sustainable Development of Ukrainian Regions: Intergovernmental Fiscal Relations and Innovative Incentive Tools: Monograph]. Lutsk: Volynpolihraf.

14. Sokhatska O.M. (ed.) (2011) Finansovyi inzhynirynh: Navchalnyi posibnyk [Financial engineering: Textbook]. K: Kondor.

15. Krysovatyi A.I. (ed.) (2016) Fiskalnyi prostir staloho sotsialno-ekonomichnoho rozvytku derzhavy: Monohrafiia [Fiscal space of sustainable socio-economic development of the state: Monograph]. Ternopil: TNEU.

16. Khatniuk N.S. (2016) Innovatsii $\mathrm{v}$ podatkovykh pravovidnosynakh yak umova rozvytku y optymizatsii podatkovoi systemy Ukrainy [Innovation in tax relations as a condition for the development and optimization of the tax system of Ukraine]. Scientific Herald of the International Humanitarian University, no. 23, pp. 80-83. [in Ukrainian]

17. Shnypko O.S. (2003) Natsionalna konkurentospromozhnist: sutnist, problemy, mekhanizmy realizatsii [National competitiveness: the essence, problems, mechanisms of realization]. K.: Naukova dumka. 